\title{
Rajojen ymmärtäminen kielellisten identiteettien avulla
}

Alicja Fajfer

Kuusi vuotta sitten, kun aloitin väitöskirjani valmistelemisen, maailma oli eri paikka kuin se on tänään. Vaikka maailma ei koskaan seisahdukaan, niin nyt näyttää siltä, että vaikeudet vain seuraavat toisiaan. Pienet vihreät miehet, pakolaiskriisi, mielivaltainen väkivalta, Brexit, mielenosoitukset sekä lähestyvä ilmastokatastrofi ovat vain muutama esimerkki maailmanlaajuisesti keskustelua herättäneistä uutisista, jotka näkyvät enemmän tai vähemmän taustalla tutkimuksessani.

Nämä asiat vaikuttavat eri tavoin tutkimuksen osallistujien elämään. Jotkut ovat järkyttäneet osallistujia syvästi, kuten Itä-Ukrainassa meneillään oleva konflikti, mutta toisia, kuten Brexitiä, ei mainitakaan. Tästä voimme oppia, että edes tunnettuja rajoja ei voi pitää itsestään selvinä. Viimeaikaiset järkyttävät tapahtumat herättävät keskustelua identiteeteistä ja muinaisina pidetyistä eroavaisuuksista. Akateemisesti minua eniten kiinnostava aihe on tulkinnanvaraiset rajat. Väitöskirjassani vastaan Stuart Hallin (2013) kutsuun tutkia identifiointia liikkuvuuden kontekstissa, koska liikkuvuus on häiriö. Liikkuvuus häiritseekin sitä olettamusta, että identiteetit olisivat annettuja ja pysyviä.

Everyday bordering in stories of mobility: Linguistic encounters in Poland on laadullinen tutkimus, jonka pyrkimyksenä on lisätä ymmärrystä siitä, miten suhtaudumme eri rajoihin. Rajat auttavat meitä luomaan identiteettejä, niin omaa kuin muidenkin: perheenjäsentemme, 
ystävien, naapurien, tuntemattomien sekä jopa niiden, joita emme koskaan ole tavanneet ja joiden olemassaolon olemme vain kuvitelleet. Me rajoitamme muita, niin kuin muutkin rajoittavat meitä. Tämä vastavuoroisuus ja konfliktin riski on se, mikä tekee identifioinnista dynaamisen prosessin. Palaan tähän aiheeseen, kun esittelen pääkäsitteeni - kitkan.

Tutkimus perustuu 15 osanottajan kanssa tehtyihin laadullisiin haastatteluihin. Tutkimuksen osanottajat ovat muuttaneet Puolaan Ukrainasta, Valko-Venäjältä tai Venäjältä. En oleta, että haastattelut paljastaisivat totuuden kaikista niistä ihmisistä, jotka ovat kotoisin itäslaavilaisia kieliä puhuvista maista. Tutkimuksen osanottajat toimivat kuitenkin osoituksena uudesta liikkuvuuden suunnasta. Heidän liikkuvuutensa on seurausta juuri tietynlaisen elämäntavan tavoittelusta. Euroopan unionissa tämä elämäntapa vaikuttaa olevan osa jokapäiväistä arkea: tähän liittyy toimeentulon takaava palkka, mutta ennen kaikkea liikkumisen vapaus. Toisaalta tällainen väite on aivan liian yksinkertaistava. Edustavan otoksen poimiminen on tuttu haaste siirtolaisuuden tutkimuksessa. Puolan tapauksessa tilannetta monimutkaistaa entisestään viimeaikaiset huomattavat muutokset liikkuvuudessa.

Puola on liikkuvuuden tutkimuksen kannalta mielenkiintoinen maa, sillä viime aikoihin asti sen väestö on ollut homogeeninen (ainakin virallisten tietojen mukaan) ja siellä on harjoitettu tiukkaa maahanmuuttopolitiikkaa. Kun aloitin tutkimukseni vuonna 2013, maahanmuuttopolitiikassa oli jo tapahtunut muutoksia. Vaikka Ukrainan siirtolaiset ovat aina olleet Puolan suurin ulkomaalaistaustainen väestöryhmä, nyt heidän epävirallista lukumääräänsä lasketaan jo miljoonissa. Väestöryhmän taustat ovat myös vaihtelevampia kuin aiemmin. Esimerkiksi monet nuoret ihmiset käyttävät korkeakouluopiskelua kätevänä tapana muuttaa maahan. Valko-Venäjän kansalaiset muodostavat myös merkittävän ulkomaalaistaustaisten ryhmän, joskin huomattavasti pienemmän kuin ukrainalaisten. Puolassa myönnetään ensimmäisiä oleskelulupia EU:n ulkopuolelta tuleville hakijoille enemmän kuin missään muussa EU-maassa. Puolasta on tullut salainen kultamitalisti työperäisen maahanmuuton saralla. Salainen, koska aiheesta ei keskustella avoimesti.

Puolan maahanmuuttopolitiikan muutokset otettiin käyttöön taiten. Uuden lain piti vähentää byrokratiaa valikoiduista maista tuleville siirtolaisille. Tutkimuksen osanottajien maat, Ukraina, Valko-Venäjä ja Venäjä, kuuluvat tähän listaan. Näiden maiden erikoiskohtelun perusteluna oli kulttuurinen samankaltaisuus. "Samankaltaisuus" tässä kontekstissa tarkoittaa kielellistä samankaltaisuutta, yhteistä historiaa sekä selkeiden kulttuuristen erojen puutetta. Samankaltaisuuden oli tarkoitus varmistaa onnistunut kotouttaminen eroista johtuvien konfliktien torjunnan avulla. Koska Puolalla ei ole virallista kotouttamispolitiikkaa, siirtolaisuus voidaan täten nähdä tämän perustelun valossa epätoivottuna, mutta välttämättömänä asiana. Vaikka en kysynytkään osanottajilta suoraan, havaitsin että assimilaatio näkyi vahvasti heidän asenteissaan. Tästä pystyin päättelemään, etteivät osanottajat yleensä ottaen pitäneet poliittista kantaa kulttuurien samanlaisuudesta ongelmana.

Taustalla oleva eron pelko kuuluu kuitenkin ehkä jo menneisyyteen. Yksikielisyys ei enää hallitse puolalaisten kaupunkien kielellistä maisemaa, mutta periferiassa tämä muutos on tapahtunut vastikään. Suurin osa aineistostani poimittiin selkeästi periferiassa sijaitsevasta kaupungista nimeltä Katowice, jonka kielellinen maisema on muuttunut huomattavasti monipuolisemmaksi. Olen kuullut paikallisten kommentoivan, että heidän kaupassa tai ravintolassa tapaamansa työntekijä puhuikin tavalla, jota he itse nimittävät "itämurteeksi". Olen myös kuullut, että venäjän kielestä on tullut osa jokapäiväistä katukuvaa.

Pääosa tutkimuksen osanottajista on ehdottomasti sitä mieltä, että Puolaan tulevien siirtolaisten tulee käyttää puolaa jokapäiväisenä kielenään. Tässä lausunnossa ei sinänsä ole mitään 
yllättävää, koska tutkimuksen osanottajat olivat muuttaneet Puolaan ennen kuin tällainen liikkuvuus oli yleistä. Silloin oli tarjolla vain vähän ukrainan- ja venäjänkielisiä palveluja, mutta nyt pankit ja teleyritykset näkevät ukrainankieliset siirtolaiset arvokkaina asiakkaina. Hiljattainen MoneyGramin ukrainankielisille asiakkaille suuntaama julistekampanja on hyvä esimerkki tällaisesta kohdistetusta mainonnasta. Kampanjan eri julisteet oli asetettu näytteille lähelle toisiaan näkyville paikoille monissa isojen kaupunkien keskustoissa, esimerkkinä kuva Katowicen päärautatieasemalta. Täytyy myös mainita, että samankaltaista venäjänkielistä mainontaa ei ole juuri ollenkaan. Osa ukrainalaisista osanottajista oli kuitenkin venäjänkielisiä, mikä herättää ajatuksia tulevaisuuden identiteettitutkimuksen kannalta.

Mainitsin jo aiemmin, että tein kenttätyöni Katowicessa, joka sijaitsee Etelä-Puolassa tiheään asutulla kaupunkialueella. Vaikka Katowice ei vaikutakaan yhtä kosmopoliittiselta

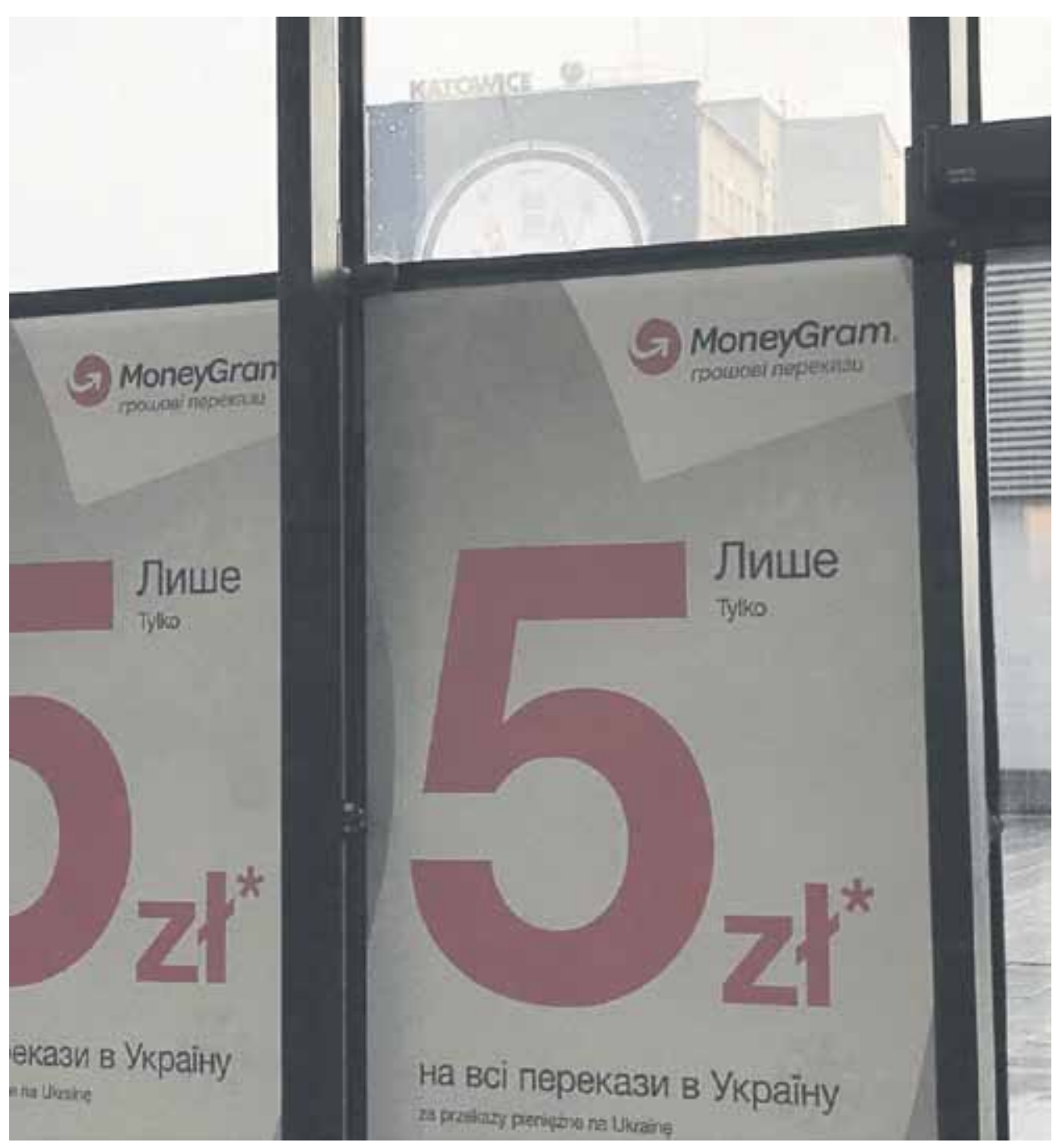

MoneyGramin ukrainankielisille asiakkaille suuntaama julistekampanja Katowicen päärautatieasemalla (joulukuu 2018). 
kuin Varsova tai Krakova, se ei suinkaan ole alueena vähemmän kiinnostava. Tutkimuksessani tarkastelen uutta siirtolaisuutta alueen myrskyisän historian viitekehyksessä. Havaitsin että paikallisesta murteesta, joka symboloi alueen vaikeaan historiaan liittyviä identiteettikonflikteja, on tullut yksi osallistujien kotoutusta helpottavista tekijöistä. Tämä siitä huolimatta, että osallistujat kuvaavatkin tätä murretta itselleen täysin tuntemattomaksi. Tässä suhteessa tutkimukseni asettaa kyseenalaiseksi maalaisjärkeen perustuvat olettamukset samankaltaisuudesta ja erilaisuudesta. Vaikka kielellinen samankaltaisuus helpottaakin vuorovaikutusta, se ei välttämättä edistä niiden ominaisuuksien omaksumista, joita tietty kieli edustaa.

Esitän tässä lainauksen, joka toimii myös väitöskirjani mottona: "Tämä varsinkin kiehtoo minua, nämä pienet yhteisöt, nämä pienet rajat". Pavel, jolle lainaus kuuluu, on varsin kosmopoliittinen nuori mies Venäjältä. Hän oppi omatoimisesti puolaa, koska se vaikutti hänen mielestään helpolta. Mutta kun hän muutti spontaanisti Puolaan, hän löysikin siellä odottamattoman maailman. Pavelin sanat toisintavat rajafetissiä, johon me kaikki olemme osallisia, sillä " nämä pienet yhteisöt, nämä pienet rajat " ovat välttämätön osa meidän jokapäiväistä elämäämme.

Miten rajat näkyvät Pavelin tarinassa? Tämä nuori mies ylitti yhden rajan, kun hän yhtäkkiä päätti muuttaa ulkomaille. Toisen kerran näin tapahtui, kun hän opetteli vierasta kieltä, mutta arveli, ettei koskaan tulisi onnistumaan. Tässä tapauksessa raja pysäytti hänet. Toisinaan hän sai apua rajojen ylittämisessä. Hän esimerkiksi ystävystyi ihmisten kanssa, jotka kohtelivat häntä kuten yhtenä omistaan. Toisaalta hän kohtasi myös ihmisiä, joiden kanssa hän ei halunnut olla missään tekemisissä. Tässä mielessä hän loi itse rajan. Vaikka nämä tarinat kuuluvatkin yhdelle henkilölle, niissä voi havaita tuttuja teemoja.

Väitöskirjani vastaa kahteen tutkimuskysymykseen. Ensimmäinen kysymys koskee samankaltaisuuden ja erilaisuuden välisiä rajoja. Minua kiinnosti, kuinka vahvaa kulttuurinen samankaltaisuus on slaavilaisten kielten puhujien kesken. Tutkitut slaavilaiset kielet olivat puola, ukraina, venäjä ja jossain määrin myös valkovenäjä. Tämä tutkimuskysymys koskee myös valtavirran siirtolaisuuspuhetta, jossa erilaisuudesta on muodostunut pakkomielle. Tämä pakkomielle tulee ilmi banaaleissa asioissa: aksentin, ihonvärin, vaatemuodin ja elämäntavan suhteen. Samaan aikaan se tuo esiin syvän pelon erilaisuudesta. Koska tarkastelen identifiointia prosessina, näen samankaltaisuuden ja erilaisuuden strategisina resursseina, enkä vain naiiveina "totuuksina".

Toinen kysymykseni koskee kielellisiä identiteettejä, jotka ovat kehittyneet rajoihin liittyvän siirtolaisuuden seurauksena. Tutkimuksen osanottajien tapauksessa rajat ylittävä liikkuvuus muutti heidän arjessa käyttämäänsä kieltä. Olen esittänyt toisen kysymykseni kommenttina kotoutukseen liittyvistä yleisistä käsityksistä. Kysymys auttaa ymmärtämään syrjintää, jota siirtolaiset kohtaavat oudon aksenttinsa tai yleiskielestä poikkeavien fraasiensa vuoksi. Heillä voi olla myös vuorovaikutusongelmia. Vaikka slaavilaisten kielten samankaltaisuus helpottaakin kielten oppimista, kielelliset samankaltaisuudet eivät poista jokapäiväisiin tilanteihin liittyviä ongelmia, eivätkä estä siirtolaisten syrjäytymistä.

Identiteettimme voi olla joustava, mutta kun vastaamme kysymykseen, keitä me olemme, tarvitsemme rajoja merkitsemään, mihin me päätymme ja missä jokin muu alkaa. Koska muut ihmiset rajoittavat meitä, identifiointi on dynaaminen prosessi, joka on usein täynnä kitkaa. Puhekielessä kitka tarkoittaa konfliktia tai riitaa. Minä kuitenkin pidän Anna Tsingin (2018) luomasta metaforasta. Hän vertaa kitkaa tiehen, jonka ansiosta joihinkin paikkoihin on helppo mennä. Muut paikat, jotka eivät sijaitse tien varrella, ovat kuitenkin saavuttamattomissa. Kitka mahdollistaa identiteettien muutoksen, mutta tulee muistaa, että muutoksilla 
on rajansa. Tämä on tärkeä opetus meidän jatkuvasti muuttuvassa ja (viime aikoihin asti) näennäisesti rajattomassa maailmassamme.

Kitka osoittaa meille, missä rajat sijaitsevat. Kitka muovaa havaintojamme samankaltaisuudesta ja erilaisuudesta. Viimeiseksi, kitka muovaa tarinoita liikkuvuudesta, koska kitka voi olla paitsi syynä epävarmuuden kokemuksille liikkuvuuteen liittyen, se voi myös lievittää eri aihealueisiin liittyvää epävarmuutta. Kielellinen epävarmuus on esimerkki kitkasta, joka ilmenee kohtaamisissa, joissa pitää kommunikoida verbaalisesti. Itse asiassa kielellinen epävarmuus on se, joka pakottaa meidät pahoittelemaan "kamalaa kielitaitoamme", jopa ennen kuin saamme mahdollisuuden käyttää kieltä. Kielellinen epävarmuus toimii myös päinvastoin, kun vältämme sellaisten ihmisten kohtaamista, joita on vaikea ymmärtää. Jos joku on siirtolainen tai ei puhu kieltä äidinkielenään, häntä voi olla vaikea ymmärtää. Siksi hänet syrjäytetään ja hän vetäytyy yhteisöstä. Yksi väitöskirjani päätelmistä onkin, että kielellisen epävarmuuden muodostamat rajat ovat vahvempia kuin yleisesti luullaan.

Yksi useimmin toistetuista väitteistä siirtolaisten kotouttamisen suhteen on se, että siirtolaisten pitäisi puhua vastaanottavan yhteiskunnan kieltä, jotta heidän "kotouttamisensa" onnistuisi. Koska väite on yleisesti hyväksytty yksinkertaisuutensa takia, se ilmenee selviönä. Vaikka väite näennäisesti vetoaakin maalaisjärkeen, kielellinen epävarmuus tuhoaa sen vetoavan yksinkertaisuuden. Jokapäiväisessä elämässä, jossa luodaan ja hävitetään jatkuvasti rajoja, kielen oppimisesta tulee rasittava tehtävä. Kielen oppiminen ei lopu, kun opiskelija suorittaa kielikurssinsa loppuun. Itse asiassa kielen oppiminen on jatkuvaa rajojen neuvottelua, jota tapahtuu niin koulussa, työpaikalla, bussissa, puhelinkeskusteluissa kuin perheenkin kesken ja niin edelleen. Jokaisella kontekstilla on omat sääntönsä, minkä vuoksi tarvitaan eri osa-alueiden taitoja. Vuorovaikutustaitojen oppimiseen ei kuulu pelkästään uusien sanojen käyttö vaan opitaan myös, että omalla identiteetillä on rajoja. Vaikka voi vaikuttaa toimivalta ratkaisulta, että vain siirtolaiset olisivat vastuussa vuorovaikutuksesta, todellisuudessa kielitaidon vaatimus voi sekä luoda mahdollisuuksia että johtaa syrjäytymiseen.

Väitöskirjassani huomautin, että kotouttaminen on puutteellinen käsite. Sen tilalle ehdotin uupumusta (fatigue englanniksi). Minun täytyy kuitenkin tunnustaa, että kotouttaminen on käsitteenä viehättävä, sillä se antaa toivoa. Kotouttamisen tarina on tarina, jolla on onnellinen loppu. Uupumus kuitenkin pitkittää onnellisen lopun kuvan toteutumista. Kun uupumus hahmottuu väsymyksenä tai antautumisena, se painottaa rajojen merkitystä. Mutta joskus se ilmenee tahtona muuttaa omat olosuhteet ja ylittää rajoja. Päinvastoin kuin kotouttaminen, uupumus käsitteenä ei kaunistele liikkuvuuden todellisuutta. Käsite on hyödyllinen, koska se opettaa meitä oivaltamaan liikkuvuuden luomia epävarmuuksia eri toimijoissa. Vaikka kielen oppiminen voi jonkin verran helpottaa kielellistä epävarmuutta, oppiminen ei poista sitä kokonaan. Muutama osanottaja mainitsi, että puolan käyttäminen jokapäiväisissä keskusteluissa on heille luontevaa. Samalla he kertoivat, että heidän äidinkielensä on saanut "aksentin". Tämän vuoksi he tunsivat epävarmuutta uusissa konteksteissa. Loppujen lopuksi, kielellinen epävarmuus koskee jokaista elämän tilannetta ja jokaista puhuttua kieltä. Uupumus painottaa sitä, että halu rakentaa reilu yhteiskunta on utopistinen unelma. Meillä ei kuitenkaan ole varaa lopettaa ponnistuksia tämän päämäärän saavuttamiseksi, sillä ei tunnustettu epävarmuus ilmenee ennakkoluuloina, jotka muuttuvat vihapuheeksi tai luovutukseksi ja johtavat lopulta avoimeen väkivaltaan tai eri ryhmien syrjäytymiseen.

Lopuksi haluaisin mainita, että olen alkanut nähdä eriarvoisuutta uudesta näkökulmasta tämän tutkimuksen johdosta. Vaikka usein olisinkin halunnut nähdä osanottajat suojattomina toimijoina, heillä oli itse asiassa käytössään varsin luovia neuvottelutaitoja, joita he osasivat 
hyödyntää hankalissa tilanteissa. Minun roolini tutkijana on "erilaisten" ihmisten reilun kohtelun edistäminen, mutta tämä ei ole mahdollista käsittelemättä epävarmuutta aiheuttavia tekijöitä. Koska kielellinen epävarmuus vaikuttaa niin syvällisesti rajojen luomiseen, minusta yhteiskunnan toimimisen tulkinta kannattaa aloittaa juuri siitä.

Englanninkielisen lektion suomennos on tekijän.

\section{Lähteet}

Hall, Stuart (2013), Introduction: Who Needs Identity? - Questions of Cultural Identity, Eds Stuart Hall \& Paul du Gay. London: Sage Publications [1. painos julkaistu 1996], 1-17.

Tsing, Anna Lowenhaupt (2005), Friction: An Ethnography of Global Connection. Princeton: Princeton University Press.

Alicja Fajferin kulttuuritieteen alaan kuuluva väitöskirja Everyday bordering in stories of mobility: Linguistic encounters in Poland tarkastettiin perjantaina 5.4.2019 ItäSuomen yliopiston filosofisessa tiedekunnassa. Vastaväittäjänä toimi professori Lara Ryazanova-Clarke Edinburghin yliopistosta ja kustoksena professori Jopi Nyman ItäSuomen yliopistosta. 